DEPARTMENT OF THE INTERIOR

UNITED STATES GEOLOGICAL SURVEY

PREPARED IN COOPERATION WITH

THE STATE OF CALIFORNIA

DIVISION OF MINES AND GEOLOGY

\title{
COMPLETE BOUGUER ANOMALY MAP \\ OF THE DEATH VALLEY REGION \\ CALIFORNIA
}

\author{
By \\ Don R. Mabey
GEOPHYSICAL INVESTIGATIONS
MAP GP-305

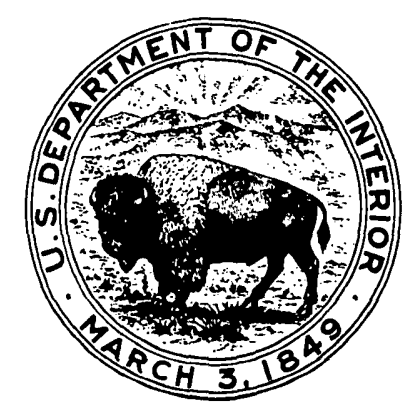

PUBLISHED BY THE U. S. GEOLOGICAL SURVEY

WASHINGTON. D.C. 